\title{
PARA UN DICCIONARIO CRÍTICO \\ DE LA NUEVA NARRATIVA VENEZOLANA
}

\author{
POR
}

Julio E. Miranda

Antillano, Laura. Nació en Caracas en 1950, compartiendo su infancia y juventud entre esta ciudad y Maracaibo. Licenciada en Letras por la Universidad del Zulia, realizó estudios de especialización en los Estados Unidos y Chile. Fue profesora de la Universidad del Zulia y lo es actualmente de la de Carabobo, residiendo en Valencia. Titiritera, guionista de cine y TV, crítica de cine y fotografia, ensayista (Los niños y la literatura, 1978; ;Ay! qué aburrido es leer, 1991), autora de un par de cuentos infantiles. Como narradora, ha publicado siete libros de relatos: La bella época (Caracas: Monte Ávila, 1969), Un carro largo se llama tren (Caracas: Monte Ávila, 1975), Haticos casa $n^{\circ} 20$ (Maracaibo: LUZ, 1975, Dime si adentro de ti no oyes tu corazón partir (Caracas: Fundarte, 1983), Cuentos de película (Caracas: Seleven, 1985), y La luna no es pan-de-horno (Caracas: Monte Ávila, 1988), y Tuna de mar (Caracas: Fundarte, 1991), además de tres novelas: La muerte del monstruo come-piedra (Caracas: Monte Ávila, 1971), Perfume de gardenia (Caracas: Seleven, 1982) y Solitaria solidaria (Caracas: Planeta, 1990).

La precocísima Laura Antillano inicia cronológicamente la nueva narrativa en 1969, acuñando varios de los rasgos que la siguen definiendo más de veinte años después: construcción de un discurso en base a fragmentos, sean los cuentos relacionados de un mismo libro, las novelas de estructuración flexible o la intratextualidad que establece un verdadero sistema de vasos comunicantes entre los diversos títulos; lenguaje coloquial; testimonio primero adolescente, luego de juventud y al cabo de adultez, mientras la "Laura de papel" crece de libro en libro, como personaje que constela en su torno a la sempiterna familia, los reiterados escenarios caraqueños, marabinos y valencianos, los medios en que se mueve (a destacar el universitario, tan poco explorado por nuestra narrativa); constante presencia del cine, no sólo como referencia a películas y actores sino mimando literariamente procedimientos cinematográficos, así como fotográficos; utilización diegética de letras de canciones (boleros y Beatles sobre todo); testimonio de la lucha armada y de la militancia estudiantil; escritura "en femenino".

La saga de la protagonista intratextual comienza en el filo entre niñez y adolescencia que registra La bella época: intimidad, frescura, lirismo, "trozos de vida", descripciones cuasi objetivistas, enumeraciones, algo - ya - de collage de textos; la casa, la escuela, la calle; la familia — desde la abuela - los hermanos, los amiguitos, los vecinos. La visión del mundo es dolorosa: suicidio, locura, pobreza; se reacciona con "buenos sentimientos" 
-lo peor del libro - pero también con la afirmación, no poco perpleja, de que "Estamos aquí".

Con la novela La muerte del monstruo come-piedra tenemos una primera síntesis: la mujer joven, madre ya de una niña, recuerda la infancia y la adolescencia; habla de luchas estudiantiles, de amigos presos y muertos; de literatura, música y cine. Un carro largo se llama tren continúa en detallamiento del mismo mundo; un cuento se dedica a la represión, las torturas, los campos antiguerrilleros; otro retrata a un joven exiliado argentino, en una muestra adelantada de este tema. Finalmente, "Carmen la que contaba dieciséis años" parte de unas fotos para evocar el pasado familiar, abuela mediante, acariciando mentalmente esmeradas caligrafías, canciones, modas: lo que llenará, como efectivo collage de textos, fotos y facsímiles de cartas, avisos publicitarios, páginas de diarios y revistas, afiches, etc., la totalizante novela Perfume de gardenia. En ella se hará articulación diegética - aunque no siempre resuelta - lo que en Haticos casa $n^{\circ} 20$ es "ornamentación" prescindible, con fotos de época del viejo Maracaibo, así como resulta mero adorno el acompañamiento no integrado - de los Cuentos de película por cierta iconografía de los mitos hollywoodenses, incluyendo - valga la broma - a la propia Antillano entre los astros del cine.

Dime si adentro de ti no oyes tu corazón partir da mayor vuelo a la capacidad fabuladora de la autora, con una escritura también más elaborada aunque persistan los descuidos (repeticiones de palabras, construcciones gramaticalmente deficientes); se destaca "La imagen", homenaje a y recreación de Imogen Cunningham retratando a su amante desnudo, quien se siente humillado por la inversión de roles. Cuentos de película sufre del catálogo de films como amontonamiento referencial y del recurso - ya para entonces manido- a los procedimientos cinematográficos, si bien brillan siempre algunas caracterizaciones femeninas. La luna no es pan-de-horno se centra en el cuento que le da título, bella evocación de la madre muerta, persistente vigencia de esa interlocutora ya imposible. Tuna de mar explora delicadamente diversos registros (un cuento "de piratas", otro "de boxeo", un hermoso ejercicio de soledad, otro que da cuerpo a la vivencia de un homosexual y el retrato de una esposa y madre en crisis).

Lo menos satisfactorio de su obra lo constituyen las dos novelas extensas. Perfume de gardenia es, sin duda, una ambiciosa totalización simultánea de la saga familiar y personal y de la historia del país en los últimos decenios, pero la cantidad de materiales heterogéneos configura quizá más una acumulación desordenada que un collage eficaz, mientras lo fragmentario contribuye a la dispersión del sentido. En cuanto a Solitaria solidaria, de escritura descuidadísima, triunfa la recreación del XIX — su crónica sentimental, si se quiere - quizá en la misma medida en que fracasa el retrato de la protagonista contemporánea.

AzuaJe, Ricardo. Nació en Altagracia de Orituco en 1959. Cursó estudios de Letras en la Universidad de Los Andes. Trabajó varios años en la Gran Sabana, dedicado a la protección ecológica. Actualmente reside en Caracas, como asesor literario de Monte Ávila Editores. Ha publicado los cuentos de $A$ imagen y semejanza (Caracas: Monte Ávila, 1986) y la novela corta Juana la Roja y Octavio el Sabrio (Caracas: Fundarte, 1991). 
Los seis cuentos de $A$ imagen y semejanza podrían repartirse en tres vertientes. La primera registra la insatisfacción existencial de hombres jóvenes hastiados de sus trabajos, sus amigos, su entorno urbano hostil o, por lo menos, indiferente, en momentos de crisis amorosa. "Madrugada del lunes" resulta el retrato más desnudo y cabal: el soliloquio del bebedor insomne en una larga madrugada, mientras su mujer - a la que ama pero de la que todo parece separarlo- duerme. "Sanguinela gens" representa, por sí sólo, una segunda vertiente: la de una fantasía sumamente sugestiva, en torno a unos seres vegetales que asesinan hombres en un poblado perdido en la selva. Finalmente, "De un porroncito con begonias" y "El paso de las montañas" plantean, cada uno a su manera, la nostalgia de la revolución. El primero mediante el desastroso encuentro de un militante que persiste en la lucha con un antiguo dirigente ahora aburguesado; el otro, indiscutiblemente el mejor cuento del libro y uno de los más interesantes de toda la nueva narrativa, registrando una crisis existencial global similar a la de otros personajes, pero que en este caso da pie para que el protagonista despliegue la brillante fábula de que las montañas de todo el mundo cobran vida y empiezan a moverse: "es lo mejor que pudo suceder, ya que no es posible la revolución, ya que no es posible un verdadero cambio, que las montañas arrasen con todo".

El tema de la revolución llena Juana la Roja y Octavio el Sabrio, noveleta deliciosamente irónica, amena, inteligente y entrañable. A través de los ojos del protagonista-narrador, joven estudiante de Derecho, apolítico, conformista, serio, algo tímido, tomará cuerpo una figura que merece integrarse en la - escueta - galería de personajes inolvidables de nuestra narrativa: Juana, su madre, aún atractiva y llena de vida, que lo tuvo a los 15 años, lo perdió de vista - a causa del divorcio-a los 30 y le cae como un rayo adorable/odioso a los 33 , conmoviendo hasta los cimientos la tranquila existencia de nuestro antihéroe. En medio de una Caracas desmantelada por los trabajos de construcción del Metro y sacudida por las puntuales noticias de enfrentamientos entre las fuerzas policiales y militares y los residuos de las guerrillas, se alza esta Juana maravillosa y patética, mujer libre en amores, madre cuasi incestuosa y militante por razones pasionales, a la que la historia condena y, al cabo, mata.

Calzadilla Arreaza, Juan. Nació en Caracas en 1959. Cursó estudios de Filosofía en la Universidad de Nanterre (Francia). Perteneció al grupo editor de La Gaveta Ilustrada. Vive en Mérida. Poeta (Réquiem a traición, 1979). Como narrador, es autor de Parálisis andante (Caracas: Fundarte, 1988) y de Álbum del insomio (Caracas: Alfadil, 1990).

Los cuarenta textos de Parálisis andante plantean un problema de definición génerica: ¿novela fragmentaria --como afirma la solapa-cuentos articulados o mezcla de ambas cosas? Me inclinaría hacia esto último, pues si bien hay piezas de lectura autónoma y otras que configuran secuencias independientes, la mayoría no lo son y, al cabo, remiten todas al mismo conjunto. En cuanto al protagonista, cambia de nombre (Zaori K., Aurelio, José Aníbal) pero no de identidad: desde el fin de la infancia hasta la vida universitaria en París, prolonga él mismo desasosiego.

En cualquier caso, los cuentos o fragmentos, hábilmente puntuados por citas de Gombrowitz que a la vez precisan y expanden su sentido, reiteran la presencia predominante de Zaori, protagonista a veces narrador, y de un puñado de muchachos y muchachas de su edad; en primer lugar, Linamazur, anagrama de la amada. Acompañando al grupo, vamos 
desde una carta-prefacio hasta "Uña tarde" (sic), en que las detalladas elucubraciones en torno a una dolorosa uña del pie se convierten en filosofia existencial: morbosa atención a las disfunciones corporales que atraviesa el libro (sudor, acné, hongos en los pies, calvicie incipiente, torpeza gestual), articulándose intertextualmente con cierta poesía (Juan Calzadilla padre, Rafael Cadenas, Arnaldo Acosta Bello, etc.) y narrativa (Salvador Garmendia) de la generación del sesenta. Si atendiéramos a la caracterización despiadada de la ciudad hostil, la conjunción temática sería aun mayor. Entre carta y uña, se suceden las ironizadas desventuras de los personajes, con una angustia ajena atenuada - si no aumentada - por su inteligente humor. La opción por lo fragmentario es, probablemente, uno de los hallazgos del libro, salvándonos de lo descriptivo para concretar, cada vez, una situación, unos diálogos, unas reflexiones, signados siempre por cierto aire de helada lucidez desesperada, a ratos discretamente enloquecida, que responde al absurdo general de la urbe, sea Caracas o París, pero también al difícil trance de la adolescencia (no olvidemos el subtítulo: "Memorias de la inmadurez").

$\mathrm{Al}$ interés intrínseco de Parálisis andante se añade su lectura en perspectiva. Además de la ya mencionada intertextualidad, se impone la referencia a Piedra de mar (1968), la novela de Francisco Massiani: ¿no encontramos en Calzadilla Arreaza una versión más desolada y dura, también más intelectualizada y formalmente variada, de aquellos devaneos juveniles sin esperanza y sin destino? Y, aún, ¿no cabría casi hablar de una especie de ritmo que, cada más o menos veinte años, propone en la narrativa venezolana el retrato en diversos momentos- de una desgarrada adolescencia, con frecuencia ligada a la aspiración escritural, si pensamos en Ifigenia (1924) de Teresa de la Parra, en Ana Isabel, una niña decente (1949) de Antonia Palacios y también en La bella época (1969) de Laura Antillano?

Por su parte, Álbum del insomnio es ya claramente una novela, aunque su estructura flexible apela nuevamente a lo fragmentario que, como en el libro anterior, es en primer lugar un registro de la fragmentación misma del personaje. Éste prolonga las constantes de aquél: torpeza, frustración, erotismo, escritura e ironía, desde una adolescencia entendida como "edad humana en la que todo es caricaturesco, inlogrado, punteado de acné y de dolores en el alma", hasta su ingreso en la vida universitaria. En perenne diálogo con una conciencia hostigante que insiste en mandarlo al siquiatra y se ceba tanto en sus fracasos sexuales como en su leve perversión; incorporando parodias (de la Ilíada, El amante de Lady Chatterley), textos suyos y ajenos, reflexiones sobre una escritura fatalmente circular y que aspira a la desnudez, así como sátiras al medio literario venezolano; dando cuerpo a apreciables personajes paralelos; registrando unos ambientes juveniles que oscilan entre la droga, la pornografia, el miedo a la policía y la pasión simultánea por la vida y la literatura, es probable que nuestro insomne protagonista no haga más que expandir el retrato ya logrado en Parálisis andante, ordenándolo y a veces subrayándolo.

Gomes, Miguel. Nació en Caracas en 1964. Licenciado en Letras por la Universidad Central de Venezuela. Traductor (Antología poética de Oswald de Andrade, 1988), ensayista (El pozo de las palabras, 1990), crítico. Es autor de dos libros de cuentos: Visión memorable (Caracas: Fundarte, 1987) y La cueva de Altamira (Caracas: Alfadil, 1992). 
Visión memorable contiene 48 textos breves, que van desde una línea hasta página y media. Aunque algunos se agoten en las usuales pequeñas sorpresas y paradojas, la mayoría resultan espléndidas cristalizaciones de una angustia caracterizadamente urbana, donde lo cotidiano acumula catástrofes, banales o fatales. Así, los protagonistas sufren bañeras que se desbordan, ratas en el apartamento, vecinos agresivos, encendedores-lanzallamas y, ya en pleno dominio de lo fantástico, monjas secuestradoras, ascensores que caen interminablemente, vagones de metro que, atrapando una hebra de la camisa, deshilvanan el propio cuerpo del sujeto ... Todo es posible, todo lo peor es siempre posible: los carros que hacen fila para aplastar a una anciana, la jauría de niños mordedores, el árbol que crece enraizado en la cabeza, el día en que los ciudadanos se dedican a gritar. Por momentos, se trata de sueños declarados, a veces unos dentro de otros, pero lo que se impone es la naturaleza pesadillesca de la "realidad" (¿cuáles son sus límites?), ya se presencie el suicidio de un comensal en su plato de sopa, se descubra a un amigo dentro de la nevera, se huya ante unos frailes criminales o, tras la expectativa, no llegue a pasar nada. La repetición de varios títulos ("Urbana", "Dies Irae", "Enxiemplo", "Nekyia", "Septiembre") estructura levemente el conjunto, que culmina con dos cuentos sintéticos como un final prolongado, recogiendo los ecos de muchos textos anteriores y culminando con la imagen de la ciudad primero enloquecida y luego abandonada por sus habitantes, menos el narrador.

Lo que en Visión memorable se da en clave fantástica u onírica, en La cueva de Altamira se presenta de manera "realista": eso y la dedicación a los inmigrantes llenan el libro. Lo primero brilla en "Travesía": la angustia de quien, en pleno centro de Caracas, se descubre sin cédula de identidad y tiembla ante la mirada de cada policía, imaginando ser deportado, contemplando redadas, atravesando la ciudad en vilo hasta su hogar en el otro extremo, soñando - nostalgia caraqueñísima - con el mar tras las montañas. También lo encontraríamos en el gallego o portugués — se apellida Couto- de "Seis, siete meses", encerrado en su casa abandonada y sucia (toda su familia se ha ido hace ya un año), detectando el olor de una rata muerta, sufriendo de insomnio ante los ruidos en torno y las llamadas telefónicas de bromistas, recordando conversaciones con los pocos amigos ("hablando de los que han muerto, de los que se fueron o de los que se irán. Esta ciudad, concluye siempre, está quedándose sola"). Otros cuentos que tratan de gallegos e italianos darían paso a los más sustanciosos, donde —como cada vez más en la nueva narrativa - el punto de vista es el del hijo de los inmigrantes, convertido en eje de la evocación tragicómica de las peripecias de los padres y concluyendo en su propio enraizamiento en una tierra que es ya la suya.

Gómez BerbesI, Iliana. Nació en Caracas en 1951. Licenciada en Letras por la Universidad Central de Venezuela. Fue profesora de idiomas. Trabaja como publicista. Es autora de tres libros de cuentos: Confidencias del cartabón (Caracas: Fundarte, 1981), Secuencias de un hilo perdido (Cumaná: UDO, 1982) y Extraños viandantes (Fundarte, Caracas, 1990).

Aunque el planteamiento de Confidencias del cartabón sea general en cuanto a la mecanización de la existencia, a nuestra progresiva condición de autómatas, a la reducción conceptual de la realidad y del arte a unos pocos esquemas rígidos, sus rasgos acusatorios se acentúan en lo que respecta a las mujeres - solas, frustradas, depresivas- que pueblan 
toda la narrativa de Iliana Gómez. Particularmente sometidas a los ritos sociales y las exigencias laborales, las distraídas, desbordadas y algo neuróticas protagonistas de una veintena de cuentos tienen dificultades para concentrarse en la búsqueda de trabajo, sufren desdoblamientos, pierden la capacidad de soñar por las noches o bien están inmersas en pesadillas. Fieles como perras, son tratadas literalmente de tales por el hombre que las abandona. Enfermas terminales, sólo aspiran a mostrar su álbum de fotos a la vecina. Radicalmente urbanas, frecuentes cinéfilas, enloquecidas a ratos, fantasiosas, autoirónicas pero también autodespreciativas, estas mujeres pertenecen a un abanico laboral casi siempre subordinado (secretarias, oficinistas, vendedoras, tipeadoras ...), que las propone como equivalentes al pequeño funcionario intertextual de la narrativa venezolana "masculina" de los años 40-60, mientras que su específica alienación femenina las relaciona con las hablantes de la poesía escrita por mujeres en la Venezuela de los 70-90.

El mismo tipo de personajes; el mismo estilo de comienzos abruptos y desarrollo a saltos; similares ironía y fantasía en una cotidianeidad levemente surrealizada, dominada por los objetos, los encontramos en Secuencias de un hilo perdido y en Extraños viandantes, aumentando en este último la extensión de las piezas, la cantidad - y el espanto- de los sueños, las calas en la infancia, los viajes al extranjero $y$, desgraciadamente, la discursividad.

IBÁÑEZ, Sael. Nació en Camaguán (Estado Guárico) en 1948, aunque reside desde muy joven en Caracas. Licenciado en Letras por la Universidad Central de Venezuela, con estudios de posgrado en España e Inglaterra. Fue miembro del grupo editor de Falso cuaderno. Ha publicado tres libros de cuentos Descripción de un lugar (Caracas: UCV, 1973), A través de una mirada (Caracas: UCV, 1978) y La noche es una estación (Caracas: Monte Ávila, 1990).

Los textos, casi todos breves, de Descripción de un lugar, presentan escasas anécdotas en tramas reducidísimas, como que están al servicio de la reflexión y la creación de "sensaciones": trátese de una reiterada situación de encierro desde la que se contempla la lluvia, desdoblándose o efectivamente bajando a la calle para ofrecer el cuerpo al aguacero; de las dificultades para moverse en el espacio urbano; de sueños o vivencias cuasi oníricas; de las edades de la vida; de la contemplación de una mujer sobre un puente, eventual suicida o prostituta, en ambos casos signada por la muerte; de la iniciación en un burdel o de fábulas de inspiración kafkiana, son cuentos - en el mejor sentido- filosóficos, considerables acaso como mínimas muestras de ensayo-ficción.

A través de una mirada dedica tres piezas al tema de la escritura: la vampirización de un autor por su crítico, quien impone su versión de la obra al punto de hacer prescindible al primero; la paralización de un segundo escritor tras su libro inicial, detenido por la originalidad imposible; el encierro de un tercero, ocupado en reescribir la literatura universal. Pero la literatura se encuentra igualmente en casi todos los demás relatos, aunque se centren en el asesinato, el amor, el incesto o el recuerdo. Un fino humor o una suave ironía impregnan el libro, en el que, como en el anterior, se rechaza la ciudad, contrapuesta ahora al mar. Excepcionalmente en la nueva narrativa, un par de cuentos se refieren a Dios, pero sólo para sustituirlo por la sensualidad y la literatura.

Ambas llenarán, con sus interferencias, La noche es una estación, libro maduro y espléndido, que con la paulatina extensión de los textos, con la atención a diversos personajes 
en espacios cerrados, con la abundancia de pensamientos y diálogos y con la concentración en un medio (la Universidad, sus profesores, sus fiestas y bares) pareciera a punto de novela. Pero no es la Universidad sino la crisis afectiva el tema del libro: un hombre que repite la misma historia desastrosa en cada matrimonio; la múltiple entrega de una mujer que desconcierta dolorosamente a quienes pretenden fijarla; un reiterado hombre mayor, a veces escritor y siempre culto, que pierde a una mujer más joven, moldeada por él. La literatura - sus modelos, su afán de apresar la existencia - es, en la práctica, un elemento de distorsión sentimental pero también un catalizador, como en el caso del profesor heterosexual súbitamente enamorado de un alumno. La amistad entre un hombre y una mujer, reiterada igualmente, resulta un soporte en medio de tanta desolación. Finalmente, un cuento de infancia utiliza el recurso a la versión onírica como comentario de los hechos.

INFANTE, Ángel Gustavo. Nació en Caracas en 1959. Licenciado en Letras por la Universidad Central de Venezuela. Máster en Literatura Latinoamericana Contemporánea por la Universidad Simón Bolívar. Ha publicado los cuentos de Cerrícolas (Caracas: Fundarte, 1987 y -edición aumentada - 1992) y la novela Yo soy la rumba (Caracas: Grijalbo Mondadori, 1992).

El mundo "marginal" - paulatinamente mayoritario- de los cerros de Caracas, registrado con abundancia por nuestro cine y que hasta las telenovelas han convertido en -más o menos idílico - trasfondo de sus melodramas interclasistas, no ha recibido excesiva atención por parte de la literatura, acaso con la excepción del teatro. Si es mejor olvidar un par de novelas mediocres en los años sesenta y resaltar, en cambio, Los habitantes (1961), novela de Salvador Garmendia, y algunos relatos de Rajatabla (1970) de Luis Britto García, es un hecho que la tematización global de Cerrícolas, en el que prácticamente nunca salimos del barrio, queda como única en el marco de nuestra narrativa hasta fechas muy recientes. No así su "estilo": ese registro de hablas; esa frialdad u objetividad en el retrato de situaciones de una violencia asumida como "normal"; esa galería de tipos casi impávidos ante una muerte que integra la materia misma de lo cotidiano como una nueva forma de tragedia, ahora radicalmente social, remitirían al mismo Britto García, a Argenis Rodríguez o a Edilio Peña. En tal sentido, lo que ofrece Infante es una "especialización" de la violencia urbana, concentrada en el modelo a escala del cerro.

Los "cerrícolas" - neologismo genial- incluyen muchachas asaltantes que son, sin embargo, solidarias con la gente de su zona; inmigrantes campesinos que no soportan la ciudad y retornan a morir a las montañas natales; amantes despechados; innumerables jóvenes ociosos, bebedores de cualquier alcohol y fumadores de marihuana, que pasan el tiempo en las escaleras, protagonizan súbitas peleas, sufren el acoso policial y se deslizan, con mayor o menor disimulo, hacia las camas de sus novias y amigas; todo un muestrario de mujeres frustradas, sean estudiantes, amas de casa o prostitutas.

Humor fantasioso y música popular como ingrediente dramático caracterizan la novela Yo soy la rumba. Fragmentaria, llegando al collage con la inclusión de recortes de prensa, metaliteraria, rocambolesca incluso, la obra abarca quizás demasiadas cosas en 130 páginas, desde un homenaje a Guillermo Meneses parodiando su cuento "La mano junto al muro" gracias al retrato de la Gorda Elisa, literal devoradora de hombres tragados por su vagina 
oceánica, hasta una recreación de los hippescos años setenta tal como se vivieron en Venezuela, pasando por el Bildungsroman del niño y luego adolescente que es su protagonista y narrador, para desembocar, en una segunda parte bastante abrupta, en la elaboración literaria de la música popular, bosquejando un anecdotario de bares, delincuentes, tipas, orquestas, cantantes y policías en que se encuentran, por cierto, algunas de sus mejores páginas.

López Ortega, Antonio. Nació en Punta Cardón (Estado Falcón) en 1957. Vivió en el Zulia y reside desde joven en Caracas. Comezó la carrera de Física en la Universidad Simón Bolívar, abandonándola por la de Letras en la Universidad Central y licenciándose en Estudios Hispánicos en la Sorbona (París). Fue miembro del equipo editor de La Gaveta Ilustrada, director de publicaciones de Fundarte, coordinador de la revista CriticArte. Actualmente, es uno de los responsables de la editorial Pequeña Venecia, director literario de Alfadil y gerente general de la Fundación Bigott. Antólogo ("Muestra antológica del nuevo relato venezolano", revista Imagen, 1986; La piel en la mirada - poesía-1992), ensayista, crítico. Como narrador, es autor de Larvarios (Cuerpo plural [Caracas: Ediciones La Gaveta, 1978]), Armar los cuerpos (Voces nuevas. Narrativa [Caracas: CELARG, 1982]), Cartas de relación (Caracas: Fundarte, 1982), Calendario (Caracas: Monte Ávila, 1990) y Naturalezas menores (Caracas: Alfadil, 1991), y coautor de la ¿novela? colectiva Ritos civicos (Caracas: La Gaveta Ilustrada, 1980).

Ante la madurez de sus dos últimos títulos, Larvarios y Armar los cuerpos van quedando como "ejercitaciones", por otra parte nada despreciables, y Cartas de relación como un verdadero gozne, en que ya se elaboran satisfactoriamente no sólo los materiales temáticos (infancia, erotismo, vida en París, viajes, crisis de parejas) sino también una estructuración en fragmentos fechados y un registro de exterioridades como soportes reflexivos que culminarán en Calendario y Naturalezas menores. De todos modos, Larvarios contiene preciosos cuentos líricos, inquietantes elaboraciones fantásticas, excesos amorosos siempre trágicos, paradojas a lo Magritte y ficciones ironizadas, en piezas siempre breves. En cuanto a Armar los cuerpos, se abre y cierra con dos relatos "autobiográficos" que podrían insertarse - así como el escenario rural de la infancia y cierto erotismos, en Larvarios - en la vida del protagonista intratextual de toda la narrativa de López Ortega. Incluir Ritos cívicos dentro de su trayectoria sería quizás ocioso, dada la redacción múltiple -ocho autores - de esta inovela? corta hecha de fragmentos (pequeñas escenas, trozos de diálogos, aforismos surrealistas, cuasi poemas en prosa).

Cartas de relación es el único libro "epistolar" de la nueva narrativa venezolana, un proyecto bien llevado a cabo, que muestra la flexibilidad del género imitado. Las cartas son autónomas pero pueden también leerse como segmentos ordenados —con vueltas atrás - de una misma existencia. Así, la "Carta a la madre", en la que el autor traza en paralelo su infancia y la de su progenitora; la "Carta al padre", ya caraqueña y más recatadamente dolorosa; la "Carta al amigo", un abanico anecdótico, meditativamente elaborado; la "Carta conyugal", seguramente la más áspera, insistiendo en las materias degradadas del cuerpo y en el miedo como único vínculo; finalmente, una "Carta mayúscula (o a mí mismo)", resumiendo la serie biográfica. 
Otra cumplida realización sistemática de un proyecto es el diario de Calendario: noventa textos breves que abarcan casi un año. Tan excepcional como el libro anterior, habría que remitirse prácticamente a la Ifigenia (1924) de Teresa de la Parra, con su epístola y su diario, o al Agendario (1988) poético-aforítico de Juan Calzadilla para encontrar algo en cierta manera similar. En Calendario, que plantea además un problema de definición genérica, pues oscila entre la narración, el ensayo y el poema en prosa, el autor combate la dispersión sensorial y mental ("Vivo constantemente lleno de signos. Voy por cualquier calle como rellenándome", es su comienzo) filtrando la multiplicidad mediante una reflexión que lo convierte todo en escritura: mujeres, libros, films, la sonrisa de un niño, una flor, su propio rostro.

Igualmente espléndido resulta Naturalezas menores, uno de los libros de mayor calidad de la nueva narrativa. Irresumible en su riqueza temático-anecdótica, la niñez, el erotismo (infantil, adolescente, adulto), las parejas - felices o deshechas - una galería de retratos femeninos, varias elaboraciones fantásticas dadas en general como cuentos-dentro-delcuento son sus ejes principales, sin olvidar excelentes piezas autónomas o articuladas como "Diario de viaje".

Mata, Humberto. Nació en Tucupita (Delta Amacuro) en 1949, pero vive desde joven en Caracas. Cursó estudios de ciencias y posteriormente de Filosofia en la Universidad Central. Ha trabajado en la Galería de Arte Nacional. Crítico de artes plásticas, antólogo (Distracciones -cuentos-1974). Es autor de cuatro libros de relatos: Imágenes y conductos (Caracas: Monte Ávila, 1970), Pieles de leopardo (Caracas: Monte Ávila, 1978), Luces (Caracas: Monte Ávila, 1983) y Toro-toro (Caracas: Alfadil, 1991).

Con los cuentos de Imágenes y conductos, Mata se convirtió - junto a Laura Antillano- en cofundador precoz de la nueva narrativa, a la que marcó, además, en varios sentidos: predominancia de la brevedad; fantasía, ropaje policial, cierto humor y cienciaficción poética; tramas levísimas, insertadas en reiteraciones rítmicas y juegos de versiones cuya síntesis de planos enrarece las anécdotas, en una escritura de engañosa nitidez; estilización del paisaje; protagonismo infantil y juvenil; distanciamiento respecto a materias altamente dramáticas (sacrificio ritual, incesto y parricidio, filicidio ...). Nada de esto, tomado elemento por elemento, era nuevo entre nosotros; sí su aparición conjunta. El cuento breve remitiría a Alfredo Armas Alfonzo, si no queremos invocar a un José Antonio Ramos Sucre al que acaso haya que releer al menos también como narrador. Estilo, paisaje, distanciamiento recordarían a José Balza, así como los peculiares usos del género policial y la ciencia-ficción, sin olvidar a Luis Britto García. Lo adolescente lo marcó Francisco Massiani y casi simultáneamente Laura Antillano. Mata, en tal sentido, sería un puente intertextual, que recoge, elabora y devuelve ciertas líneas de la literatura venezolana anterior y paralela -incluyendo, no menos, aportes de Cortázar, Bradbury, Borges y Kafka - fijándolas como rasgos definitorios de la producción nueva, al comienzo mismo de los setenta.

Dos tipos de cuentos cabría distinguir en Imágenes y conductos: los propiamente fantásticos y aquellos en que el estilo, con su red textual, distorsiona anecdotarios verosímiles. Entre los primeros, destacaría "Continuos", con esa isla que quiebra la cotidianeidad familiar y al cabo deja preso en ella al protagonista, pero sin anular la 
"realidad" anterior: se intercambian cartas, y la poesía fantacientífica de "Jinetes de la luz". De los segundos, la tragedia juvenil de "She's a rainbow", contada cual delirio; el crimen perfecto de "El plan" y el imperfecto de "Como en un cuento", joyas ambas de cinismo y humor.

Con Pieles de leopardo se instala en la narrativa de Mata la influencia - a veces aplastante- de Borges, perceptible desde la atracción por oscuros hechos de violencia que sólo importan en cuanto sus diversas versiones dan lugar a un texto, por el comentario - fatigoso, excesivo - de uno o dos sucesos incapaces de soportar tanta adjetivación y hasta por el mimetismo de las frases. Desde luego, esto no da cuenta de sus $\mathbf{2 5}$ ficciones, en las que se expande el tratamiento del Delta como un territorio mágico de "canos que nunca terminan y colores puros", reiterando una situación de nostalgia y temible regreso desde la ciudad al pueblo natal, que será una constante en sus libros posteriores. Apreciables elaboraciones fantásticas, oníricas, de ciencia-ficción, de encierros, de cambio de identidades, etc., completan la serie, que incluye, por otra parte, varios cuentos relativos a la lucha armada, tema al que el estilo de Mata ofrece contribuciones peculiares.

La maquinaria borgiana, capaz de homogeneizar —o triturar- los asuntos habituales de Mata (el Delta, las vueltas desastrosas, la sustitución de identidades, los amigos enamorados de la misma mujer), se impone en Luces. Una perla: "Vibráfono" - la música es otro de sus rasgos persistentes. Un aporte a un género escaso entre nosotros: "El cansancio de A. P. Frachazán", insertando los crímenes del viejo policía en el desciframiento topográfico de la Caracas colonial y en una historia violenta que comienza con la fundación misma de la ciudad.

Toro-toro resulta mucho más satisfactorio. E1 relato que da título al conjunto explicita la ya mencionada situación intratextual: "esto ya sucedió en otra parte, quizá en algún cuento: él se marcha por un día o dos, máximo una semana, tal vez más, y regresa luego de veinte años". La vuelta, aquí, se entrelaza con otro intratexto: la voluntad de mantener en vida a un muerto. El escenario deltano propicia los mejores cuentos. Aunque "yo, el escribiente" siga llevando el relato de la mano y comentándolo, hay una nueva serenidad e incluso una sensualidad que impregnan el discurso, haciéndolo fluir como las aguas siempre presentes.

Peña, Edilio. Nació en Puerto La Cruz (Estado Anzoátegui) en 1951. Reside desde hace años en Mérida. Guionista de cine, director y profesor de teatro, trabaja como tal en la Universidad de Los Andes. Dramaturgo (Resistencia, 1973; El círculo, 1975; Los pájaros se van con la muerte, 1980; Retrato de Van Gogh, 1991, entre otras piezas) y ensayista (Apuntes sobre el texto teatral, 1979). Como narrador, es autor de los libros de relatos: Cuando te vayas (Caracas: Monte Ávila, 1978), Más allá de las ramblas (Caracas: Monte Ávila, 1983), El último regalo (Caracas: Fundarte, 1985) y Los ausentes (Caracas: Fundarte, 1991).

Resulta prácticamente inevitable afiliar la escritura de Peña a la de Argenis Rodríguez, no sólo por la narración directa hecha en base a escenas fragmentarias que tienen un fondo novelesco común, con un protagonista al que se sigue de libro en libro, sino también por la materia dramática coincidente que se entrelaza en torno a ese joven que viene a "triunfar" en Caracas desde su miserable pasado rural: vida de hambre, pensiones, bares, prostitutas, 
literatura, experiencia española, con el fracaso de la lucha armada como trasfondo. Es, por otra parte, también evidente que la literatura de Peña se ha ido diversificando y enriqueciendo a partir del anecdotario y el estilo compartidos con Argenis y a ratos con Salvador Garmendia, así como se relaciona con sus propios textos teatrales.

La saga comienza con los cuentos de Cuando te vayas, cuyos segmentos biográficos pudieran ordenarse desde la infancia en diversos lugares del oriente del país, al azar de los destinos del padre, militar borracho, mujeriego y violento. Los sufrimientos de la madre y las palizas al niño serán frecuentes. La familia está signada por la locura y el mismo protagonista aparece una vez con camisa de fuerza e inyectado. Costumbres sexuales de la adolescencia; recluta; algún trabajo y sobre todo un deambular desesperado, con amigos y mujeres. Después, la Caracas de barrios y zonas populares: hambre, teatro, lecturas, sueños revolucionarios, cine, cervezas, sexo. También: policías, luchas reprimidas, encarcelamientos, una bomba que explota demasiado pronto, torturas, estudiantes muertos. $\mathrm{Al}$ cabo, encontramos al protagonista hospitalizado tras una golpiza. El último cuento revierte sobre el conjunto: a punto de cumplir 25 años y con una hija, quiere llevar al papel ese pasado doloroso.

Más allá de las ramblas comienza, a su vez, con otra escena escritural: tiene en las manos el cuaderno en que tomó notas de su estancia española; ofrecerá "estos fragmentos". La "novela fragmentaria", rasgo común de buena parte de la nueva narrativa, continúa, favorecida ahora por la limitación espacial (Barcelona) y temporal (varios meses), mientras que el "realismo" anterior se permea con sueños y escenas delirantes, de humor absurdo y cruel, retratando una España aún franquista, buñuelescamente religiosa, reprimida y represora, feroz. E1 protagonista-narrador acude también al registro de diálogos, a cartas, monólogos de personajes anónimos, descripciones objetivistas.

El último regalo nos retrotrae al mundo del primer libro: áspero enfrentamiento con el padre; un sueño de la madre y uno suyo, con ella como protagonista; relaciones con su ex mujer, a la que saca dinero; la frustración de un profesor de teatro que ni siquiera tiene donde vivir. En cuanto a Los ausentes, el relato que lo titula prolongaría a nuestro persistente antihéroe, ahora con 38 años y un exacerbado deseo de hacer algo importante antes de los 40 , pero por otra parte pareciera un retrato generacional de rasgos acusadamente irrisorios, aunque se utilice un material biográfico similar. En otro sentido, se destaca "El dragón amarillo", más bien novela corta que relato extenso, que culmina la capacidad fabuladora de Peña: aunque no lo desarrolle como policial, hay una excelente intriga en el sugestivo decorado de un hotel de placeres; varios personajes de interés; una trama apretada, que mantiene el suspenso.

Quintero, Ednodio. Nació en Las Mesitas (Estado Trujillo) en 1947. Vivió en diversas localidades del mismo Estado, estableciéndose finalmente en Mérida desde hace casi treinta años. Ingeniero forestal por la Universidad de Los Andes, donde ejerce como profesor. Fue director fundador de la revista Solar y de las ediciones del mismo nombre y organizador de la ${ }^{\circ}$ Bienal Nacional de Literatura "Mariano Picón Salas". Guionista cinematográfico, ensayista, antólogo (Narradores andinos contemporáneos, 1980). Como cuentista, ha publicado: La muerte viaja a caballo (Mérida: La Draga y el Dragó, 1974), Volveré con 
mis perros (Caracas: Monte Ávila, 1975), El agresor cotidiano (Caracas: Fundarte, 1978), La linea de la vida (Caracas: Fundarte, 1988) y Cabeza de cabra y otros relatos (Caracas: Monte Ávila, 1993). Es igualmente autor de la novela La danza del jaguar (Caracas: Monte Ávila, 1991) y de la noveleta La bailarina de Kachgar (Mérida: Solar, 1991).

Narrativa de ecos, de reflejos, de circularidades múltiples, de borradores que se van afinando a cada nueva versión; de crecimiento vegetal, orgánico, recorrida por una misma savia, siempre enriquecida: en cualquier lectura salta a la vista el carácter reiterativo de toda la obra de Quintero, en dos aspectos complementarios: por una parte, un sistema de palabras claves, de imágenes, de metáforas que vuelve, una y otra vez, tomadas de la naturaleza e insertadas en un discurso suntuosamente sensual; por otra parte, la cíclica reasunción de temas, situaciones, escenarios, personajes, hasta de cuentos enteros.

La muerte viaja a caballo, por encima de su calidad desigual, ha resultado una cantera en cuyos más ricos filones Quintero se ha ido adentrando poco a poco. Ya están ahí la serie relacionada de incesto, parricidio y venganza; el encierro, con la polaridad entre el encerrado y su antagonista (su doble o la mujer liberadora); las metamorfosis; el esquema del Western (duelo y trasfondo testimonial de violencia rural); un imaginario hecho de creencias tradicionales pero que echa raíces en lo arquetípico; finalmente, las "perversiones", desde un erotismo provocador, de ribetes sacrílegos, hasta el canibalismo. Y, en el plano formal, la circularidad de la narración misma que, con la textura lírica de su lenguaje, constituyen la base del barroco quinteriano.

Volveré con mis perros reproduce el único cuento no breve del conjunto anterior, "La puerta": el eros como sola salida, la mujer como destino del protagonista monologante que imperará cada vez más en esta narrativa, hasta convertirse en un teatro de la conciencia. Exploraciones de infancia, una pieza de ciencia-ficción, un crimen perfecto, un relato sintético como "Rosa de los vientos" (incesto, amor infantil, odio al padre admirado) completan el libro. Por su parte, El agresor cotidiano es una obra espléndida, en la que varios relatos llevan a la perfección sendas líneas intratextuales: la metamorfosis en perro, el encierro, el doble, el eros infantil y sacrílego, la mujer mágica.

Tras un silencio de diez años, La línea de la vida retoma doce de los textos mínimos de La muerte viaja a caballo, reelaborados ahora con la densa prosa lírica ya habitual en su autor, agregándole nuevas piezas. La misma operación de reescritura, aplicada ahora a 44 de los 65 cuentos que componen su obra, la encontramos en Cabeza de cabra y otros relatos, ahondando los materiales anteriores.

De alguna manera, la plenitud del mundo quinteriano, suficiente y autónomo; la compacta intratextualidad; la persistencia de un soliloquio que, en distintas edades de la vida y al azar de múltiples aventuras, mantenía un mismo tipo de protagonista, pedían su expansión a las dimensiones de la novela. Y así La danza del jaguar cumple con las expectativas de la cuentística, culminando esa especie de teatro de la conciencia del personaje monologante, en escenarios ahora multiplicados que van desde la montaña y la selva hasta Europa y Africa, mientras las peripecias, los disfraces, las versiones, los desdoblamientos pero también los encuentros se acrecientan y se potencian, tornando ígneo el erotismo de muchas páginas. ¿Novela-río - a escala venezolana en cuanto a la extensión? ¿Bildungsroman? ¿Periplo iniciático? ¿Poema en prosa? Todo eso seguramente, y más. Es probable, por otra parte, que la novela corta La bailarina de Kachgar, publicada casi al 
mismo tiempo, quede presa para el lector en el círculo mágico de La danza del jaguar, como si fuera una más de sus eventuales facetas. Pero acaso también ocurra lo contrario: que prefiera el ceñido marco de sus sesenta páginas para que un protagonista similar vivencie apretadamente un eros maravilloso, enraizado en la infancia, con el personaje femenino más atractivo de toda la narrativa de nuestro autor. 
